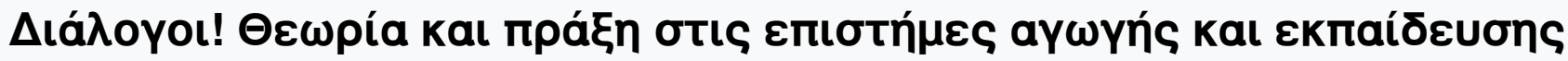

Tó 3 . 3 (2017)

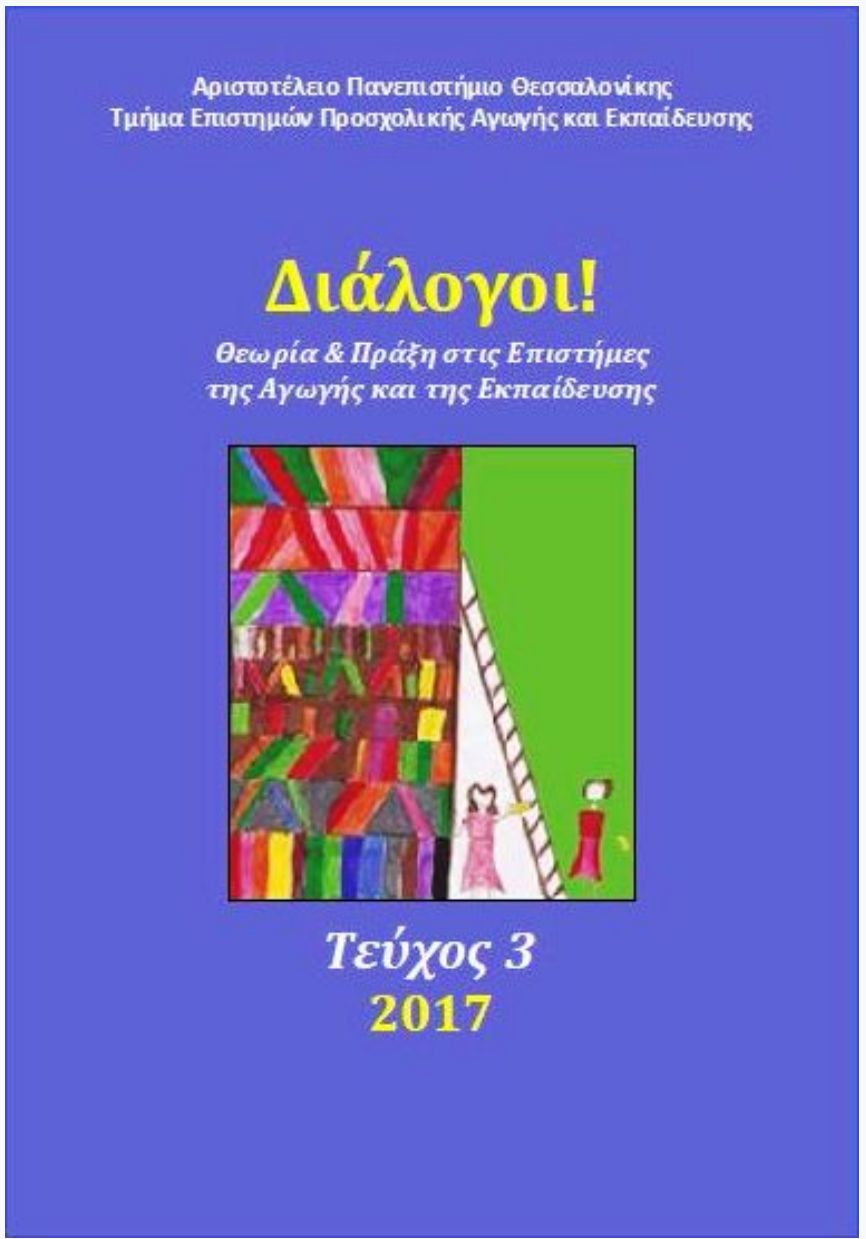

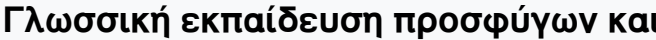

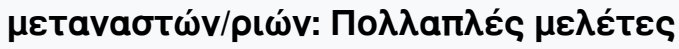

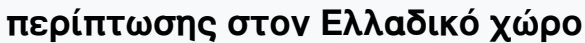

\section{Vicky Kantzou, Polyxeni Manoli, Anna Mouti, Maria} Papadopoulou

doi: $10.12681 /$ dial. 15000

Copyright $\odot$ 2017, Vicky Kantzou, Polyxeni Manoli, Anna Mouti, Maria Papadopoulou

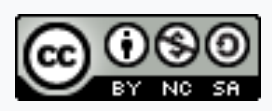

Ađฮsıa Xpńбnৎ Creative Commons Attribution-NonCommercial-ShareAlike 4.0.

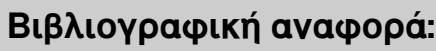

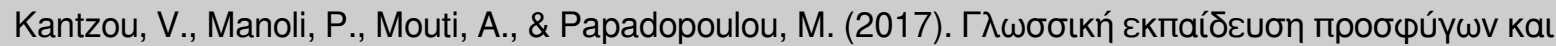

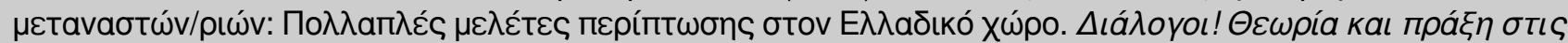

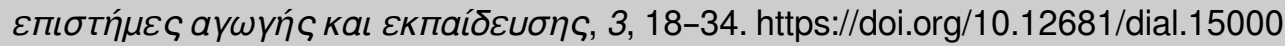




\title{
Language education for refugees and migrants: Multiple case studies from the Greek context
}

\author{
Vicky Kantzou \\ Hellenic Open University
}

Anna Mouti

University of Thessaly \& Hellenic Open University

\author{
Polyxeni Manoli \\ Hellenic Open University
}

Maria Papadopoulou

University of Thessaly

\begin{abstract}
The aim of this study is to probe into the methods, approaches, and principles used in educational environments, both formal and non-formal ones, throughout Greece that address immigrants' and refugees' language needs. The data were collected in the context of the Postgraduate Programme "Language Education for Refugees and Migrants" at the Hellenic Open University, particularly within the module "LRM50: Applied Linguistics and Second Language Acquisition". Observation tools and interviews with the teachers and students were used to collect the data, in the various second language learning environments. More specifically, the focus was on: a) teachers' and students' profile and goals, b) learning/teaching language procedures, c) teacher-student relationship and student relationship, and d) educational materials. The data were analyzed through the content analysis method. The results of the study explicitly show the fragmentation of the relevant field and highlight the need that people working in the field have for assistance and guidance in the development and implementation of educational interventions.
\end{abstract}

Keywords: Second/foreign language teaching, language education for refugees and migrants, didactic approach, literacy, educational material

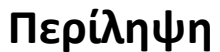

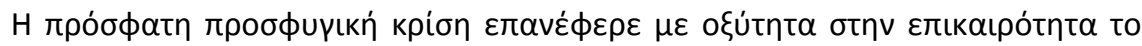

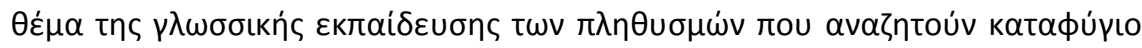

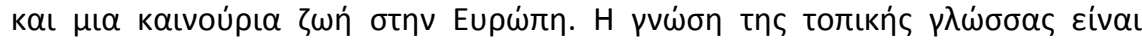

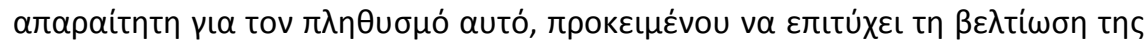

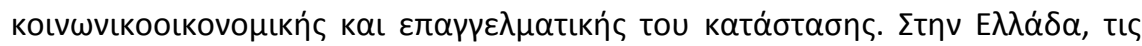

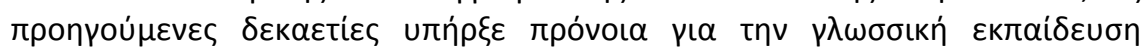

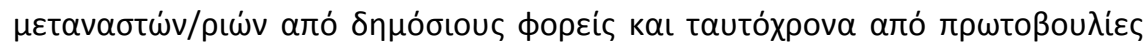

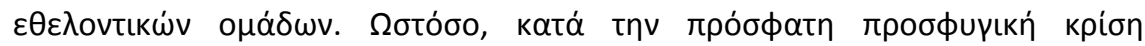

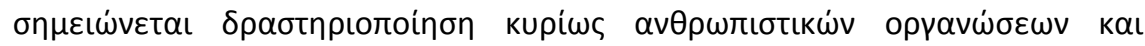

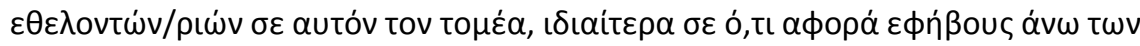

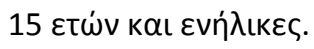

Correspondent author: Vicky Kantzou, Tutor, Hellenic Open University, vickykantzou@hotmail.com 


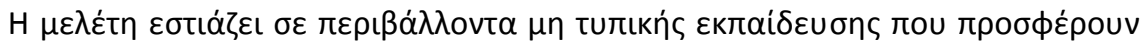

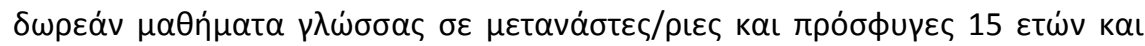

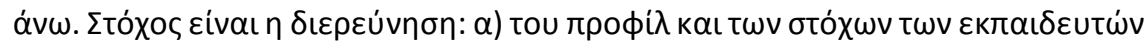

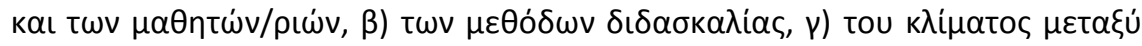

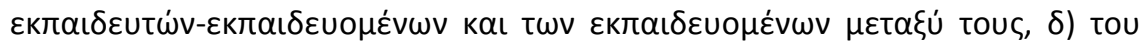

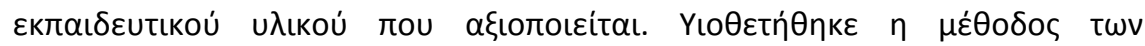

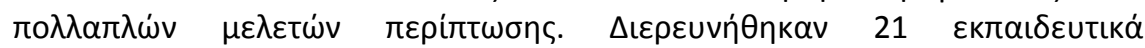

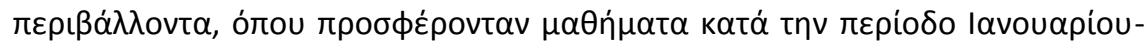

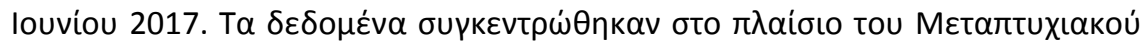

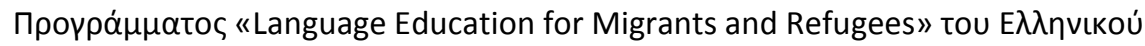

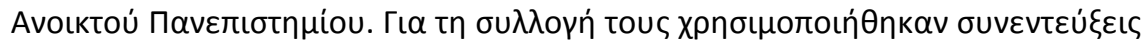

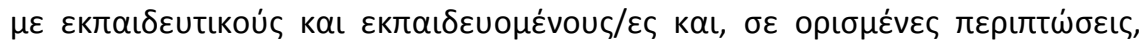

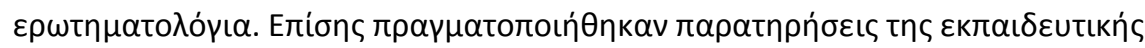

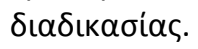

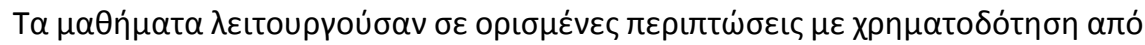

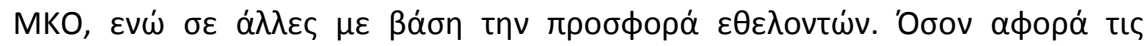

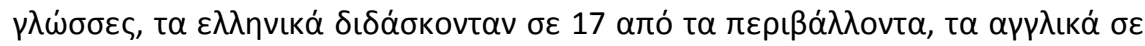

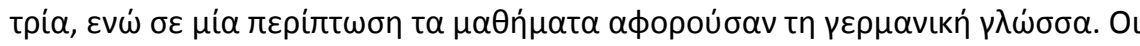

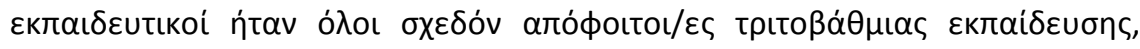

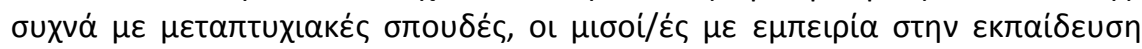

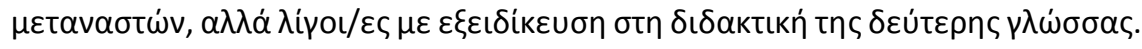

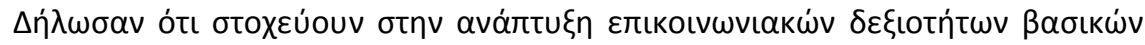

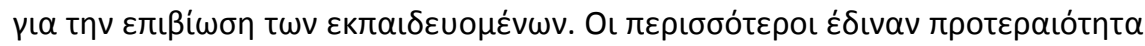

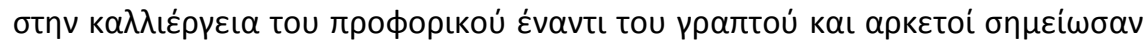

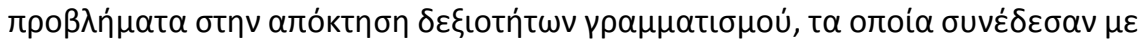

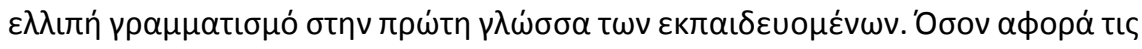

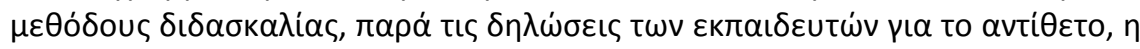

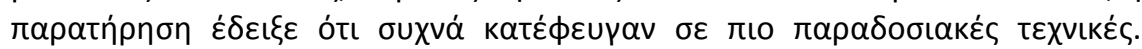

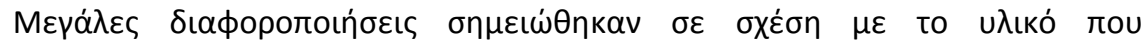

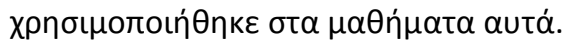

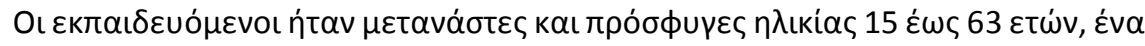

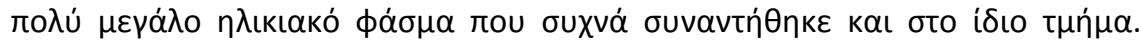

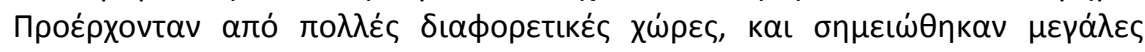

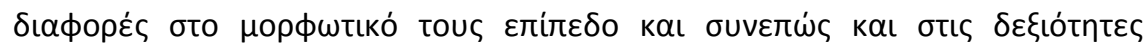

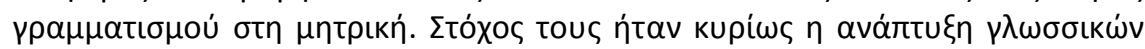

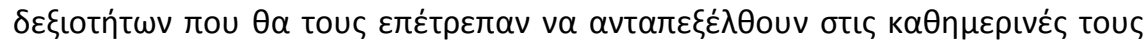

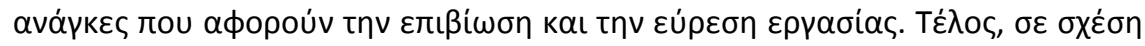

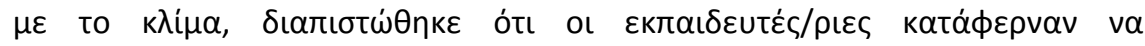

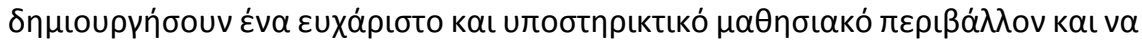

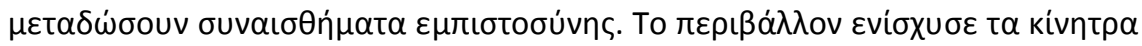

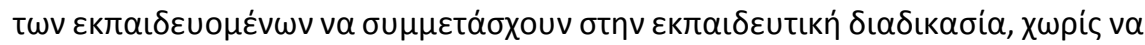

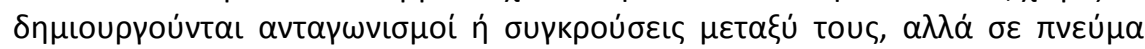

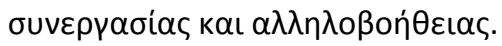

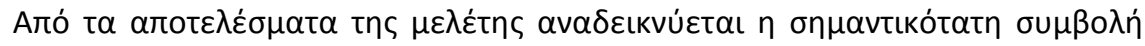

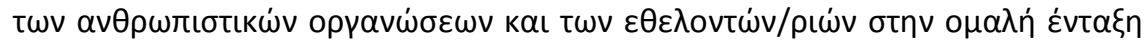

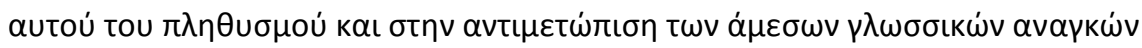

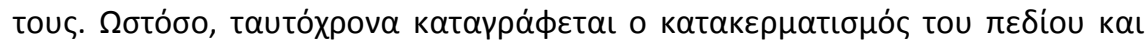

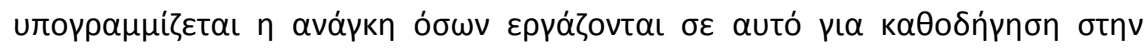

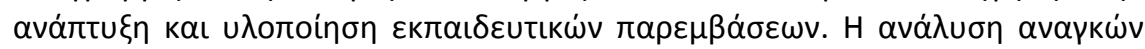

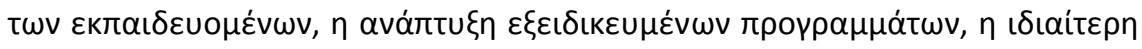

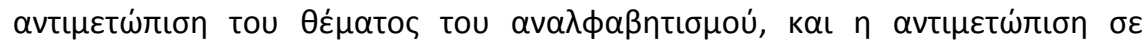

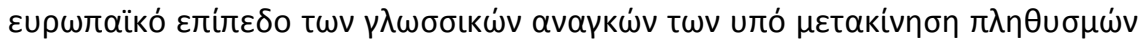




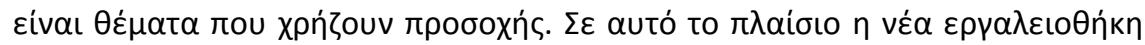

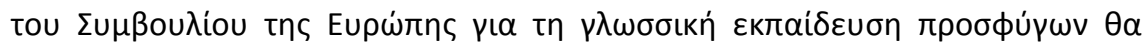

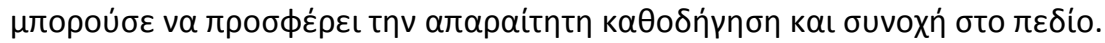

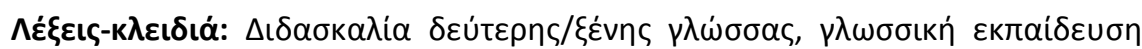

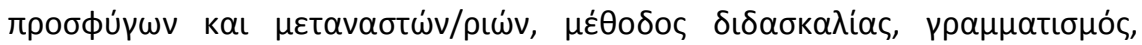

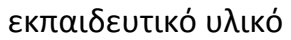

\section{Introduction}

There is no doubt that nowadays new language learners have emerged, as regional conflicts, poverty, religious and political oppression have led millions of language learners involuntarily to seek refuge in countries in which their first language is not the official language. Knowledge of the local language is a necessary tool for the refugees and migrants to improve their socio-economic and professional status (Androulakis, Mastorodimou, \& van Boeschoten, 2016). As mentioned by Krumm and Pultzer (2008), "from the perspective of the receiving society there is a danger that migrants may be considered as "speechless", because they are not able to use the language(s) of that country" and therefore speaking the language(s) of the receiving country "usually plays an important part in the process of integration, because it is a precondition for participation" (p. 72).

In this context, an increasingly vast number of people are seeking instruction in a foreign or second language (L2) turning language classrooms into heterogeneous places, as these populations differ in age, gender, socio-cultural background, first language, interests, language learning purposes, language aptitude, motivation, intelligence, educational achievement, and prior exposure and current access to the target language(s) affecting language acquisition in or out of classrooms (Beacco, Krumm, \& Little, 2017; Long, 2014). As a result, teachers' work in these educational settings becomes even more demanding, forcing them to seek for specialization in working with immigrants and refugees. In this way, what is needed is a flexible approach including a set of psycholinguistically and philosophically motivated principles whose realization will vary systematically at the level of pedagogic procedures and a careful learner needs analysis ${ }^{1}$ taking into account learners' individual differences and goals (Long, 2014). The importance of needs analysis has been given prominence in the case of migrant populations, where smooth integration has to take into consideration both the needs of migrants and those of the host community (Little, 2008; Van Avermeat \& Gysen, 2008).

Another parameter that needs to be taken into consideration in immigrant and refugee educational settings is that this population has often had limited or disrupted access to education due to the adversities they have experienced prior to re-settlement. The problem of illiteracy in their own native language is common and significantly affects their ability to acquire a new language highlighting, thus, the need for programs specifically designed to suit their needs (Bigelow \& Schwarz, 2010; Fanta-Vagenshtein,

\footnotetext{
${ }^{1}$ Following the Council of Europe's pioneering work, it is helpful to distinguish between social (sometimes called objective needs) and individual needs (sometimes called subjective needs) as presented by the Council of Europe in https://www.coe.int/en/web/lang-migrants/tailor-madecourses.
} 
2011; Marrapodi, 2013). The Council of Europe, in an effort to help institutions and teachers to provide tailor-made and learner-oriented courses, proposes a classification of four migrant profiles in terms of literacy: pre-literate, illiterate, semi-literate and literate adults (https://www.coe.int/en/web/lang-migrants/literacy-profiles). The varied characteristics and needs of each group of learners should be taken into account when designing literacy related courses, as literacy is considered a fundamental parameter of smooth integration.

As far as Greece is concerned, the influx of immigrants over the last decades has sharply increased the demands for adult language education. To address the needs of this population, special language training programs have been implemented by Ministries, local Municipalities, Universities and Vocational Training Centers; despite the many difficulties and shortcomings of these programs (Mattheoudakis, 2005; Rodakopoulos \& Lily, 2010), this population has been offered a helping hand in their effort to become independent, self-sufficient and productive members of the society. For instance, Androulakis, Gkaintartzi, Kitsiou, and Tsioli (2017) report on two nationwide research projects (ELMEGO and MATHEME) implemented by the Greek Language and Multilingualism Laboratory of the University of Thessaly, Greece, from 2010 to 2015, which offered second language courses to adult immigrants. Namely, the ELMEGO project intended to plan and implement specialized courses in Greek language for immigrant parents with children attending compulsory education and the MATHEME project aimed to design and implement Greek courses for immigrant target-groups, who were immigrants from non-EU countries, unemployed, mothers, immigrants with disabilities and illiterate immigrants. In addition to these efforts to tackle the issue of adult language education, a number of NGOs and community based organizations of volunteers have been offering Modern Greek language classes. A study by Pathiaki and Simopoulos (2014), which explores the views and practices of volunteer teachers, shows that, while these teachers may not possess the appropriate know-how with regard to language teaching and often resort to traditional educational techniques, they succeed in creating a supportive learning environment, communicating effectively, and empowering their students, who are truly enthusiastic about attending the courses.

The refugee crisis over the past few years has brought the whole issue into the foreground one more time. In particular, Greece in this recent crisis has mainly been a transit country. However, the picture has recently started to change as more and more people are urged to stay in Greece waiting to be permitted to move on, mainly for unification with family members in other EU countries. As a result, Greece is now starting to address the education of refugees staying in Greece either temporarily (i.e. in camps) or for longer periods of time. The Ministry of Education has developed a programme for the education of refugee children aged 4 to 15 , which is being implemented with the aid of major humanitarian NGO's. Nevertheless, no specific project has been developed so far to address the need for language education of adolescent and adult migrants with a refugee status. As the Greek Council for Refugees (2017) reports "although the refugee education programme implemented by the Ministry of Education is highly welcome, its implementation rate is slow, while a significant gap remains in the provision of pre-school education, senior secondary (over the age of 15), higher education and vocational training" (para. 4). At the same time, in an overview about refugees and adult education in Europe by the European Commission it is mentioned (Zarifis, 2016): 
Most educational initiatives are organized by NGOs in large cities and are mostly targeting refugee children and less adults. [...] Despite such efforts the adult education field in Greece has not come with a clear agenda or a plan regarding this issue. NGOs organising basic adult education on a non-formal basis to refugees in Reception Centres seem to be more active in terms of provision, but more synergies among the NGOs and existing local adult education structures like KDVMs (Local Lifelong Learning Centres) is needed. Resources are currently extremely low. (para. 5-7)

Although in Greece the setting is not clearly formulated and organized, in Italy, course planning and language assessment tools for Italian as a $\mathrm{L} 2$ have recently been developed and more specifically the project "Italiano L2 in contesti migratori: Sillabo e descrittori (IL2S)", which is based on the Common European Framework of Reference for Languages (CEFR) (Council of Europe, 2001) and addresses immigrant populations. Focusing on preliterate, illiterate and semi-literate adults, IL2S sets standards and recommends criteria for teaching both literacy and $\mathrm{L} 2$ in relation to the different literacy profiles (Minuz \& Borri, 2017, p. 358)2. As Minuz and Borri (2017) mention, "the need to identify descriptors of language proficiency for first levels in migration contexts specifically, for levels that are lower than those of the CEFR, has become more and more apparent in many member states of the Council of Europe" (p. 357). No systematic nationwide research has been conducted so far in Greece concerning language education for adult refugees and migrants. However, in 2016 the Hellenic Open University set up a specialized postgraduate programme (Language Education for Refugees and Migrants) aiming to train those involved in Refugee/Migrant Education as well as a major research programme (PRESS), which attempts to map the needs for language education for the groups concerned.

The present study focuses on language education offered to refugees and migrants in Greece, where Modern Greek is the dominant language. In this context, language teaching is heavily implicated in the social reality of the host country, as learners need mainly Greek to communicate in daily life and improve their socio-economic status (Androulakis et al., 2017). In this way, this study intends to explore non-formal educational settings that offer free language courses to immigrants and refugees aged 15 and above, as, according to literature research, this group seems to be a rather neglected one (Scientific Committee in Support of Refugee Children, 2017). At the same time, there is little evidence shedding light on what is going on in these educational settings. The primary research questions of the study are the following:

- Under what conditions do these language courses operate?

- What are the teachers' and students' profiles and goals?

- What are the teachers' perceptions and educational practices?

- What is the classroom climate in these educational settings?

\footnotetext{
2 “- Pre-Alpha A1, for pre-literates: non-educated adults, whose mother tongue is not written or is not the medium of schooling in the country of origin.

- Alpha A1, for illiterates: adults who cannot read and write in their mother tongue and have never been educated.

- Pre-A1, for semi-literates: adults who received a low level of education in their mother tongue or partially lost their literacy skills because they do not read and write.

- A1, corresponding to the CEFR level, for literates" (Minuz \& Borri, 2017, p. 358).
} 


\section{Method}

This study belongs to an exploratory research context, which aims to determine the nature of the problem and investigate the research questions without intending, however, to offer final and conclusive answers to the research questions. It is regarded as a primary research, as its main aim is to explore the existing situation in the Greek context, forming the basis for further research in a field where little previous research has been conducted. To this end, a research design of multiple case studies has been selected. More specifically, students attending the Postgraduate Programme "Language Education for Refugees and Migrants" at the Hellenic Open University, particularly the module "LRM50: Applied Linguistics and Second Language Acquisition", visited educational settings where migrants and refugees can attend free language classes. In this way, twenty one (21) educational settings were investigated throughout Greece over a period of six months, from January to June 2017. These settings were mainly located in Attica (11 settings), while the rest were scattered around Greece ( 5 in Thessaloniki, 2 in Volos, 2 in loannina and 1 in Kozani).

\section{Research instruments}

The research instruments used in this study were mainly qualitative. Namely, interviews were conducted with both teachers and students that provided the data. In addition, classroom observations were carried out in the various educational settings. In cases where an interview with the student was not feasible, short questionnaires were administered instead. A combination of information sources was pursued in this study in order to validate and verify research findings (Patton, 1990). However, it should be mentioned that the same research tool was not possible to be used to collect the data in all cases, as, for example, a different interview guide was designed and used in each educational setting, which could be considered one of the limitations of this study.

\section{Teachers' interviews}

In most cases, semi-structured or structured interviews were conducted with the teaching personnel at the various non-formal educational settings around Greece that offer language courses to refugees and migrants with the aim of probing into their perceived language practices. Semi-structured interviews were mainly chosen as, though they depend on pre-designed questions, they, simultaneously, allow for greater flexibility (McDonough \& McDonough, 1997). To be more precise, 21 interviews were conducted at the different educational settings, each of which lasted from 10 to 30 minutes approximately. All interviews included some background questions to delineate teachers' profile (e.g., qualifications, working experience) as well as questions about the specific components of the language teaching process and the classroom climate (e.g., the method of instruction, the educational materials, the language skills emphasized, the relationships between the teacher and students). Moreover, most of the interviews were recorded with the consent of the interviewees and transcribed verbatim for further analysis and objective recording of the data (Nunan, 1992).

\section{Classroom Observation}

Direct observations of immigrant and refugee language lessons were conducted at 21 non-formal educational settings across Greece investigating the language learning procedures followed in every setting. Namely, classroom observations focused on the 
teachers' instructional behaviors, choices, aims as well as on student interaction with their peers and teacher. The amount of each classroom observation varied depending on the amount of time allocated to each language lesson, though the goal was to observe the language lessons occurring in these educational settings at least twice or three times (from 3 to 5 teaching hours in every case). The researchers were complete observers without interrupting the whole teaching process (Iosifidis, 2003); the observers sat at the back of every classroom and wrote down instances of instructional practices in the form of field notes, as they occurred in pre-designed sheets (McDonough \& McDonough, 1997). Data included comments about each teacher's approach to language learning, the educational materials, the language skills emphasized, the teacher-student relationship and any other practice that seemed worth noting. It has to be noted, though, that each researcher was responsible for developing her/his own observation sheet based on a common set of observation objectives. Simultaneously, in some cases, photographs were taken and interactions and events were tape-recorded, as they occurred in actual classrooms for further analysis, a process that frees the researcher from the restrictions of real time (McDonough \& McDonough, 1997).

\section{Students' interviews and questionnaires}

In order to investigate students' needs, background and views, different data collection methods were followed. In certain cases, researchers opted for semi-structured interviews with the students, which were conducted either in Greek or English, while in other cases questionnaires including close and open-ended questions were developed and administered. It should also be noted that in some cases where the recording of interviews was not allowed ${ }^{3}$, the postgraduate students kept detailed field notes. The duration of each interview ranged from 10 to 30 minutes, while the questionnaires were rather short to facilitate the students' comprehension. Whenever interpreters were available at the setting, their assistance was sought, as their aid was considered necessary for the successful communication with the students, since their proficiency level limited their ability to express themselves. However, this research did not aim to investigate the profiles of the interpreters who work in these settings, and as a result, no further data were collected. Nevertheless, we believe that their profile and contribution should be investigated in a future study, as their role in the initial stages of migrants and refugees' integration is of key importance.

\section{Data analysis}

The data coming both from the interviews and classroom observations were analyzed through the content analysis method. This method included studying the data line-by-line in order to identify important information and organize it into categories based on personal knowledge or literature (McDonough \& McDonough, 1997; Schreier, 2014). In other words, once the interviews were transcribed, the researchers studied the interview data line-by-line several times until they reached a coding of the most salient information according to the aims of the study, which would help them organize the data and find answers to the research questions (Ryan \& Bernard, 2000). For instance, all the

\footnotetext{
${ }^{3}$ Some of the teachers were not feeling very comfortable with the recording procedure, as they thought of this as an evaluation procedure and therefore did not allow the recording. In these cases, the field notes were very detailed and the students/researchers used a very detailed structured interview checklist.
} 
data referring to the teaching materials were grouped under the category of 'educational materials'. The same procedure was applied to the data coming from the classroom observations with the aim of triangulating the data. The aim of the current analysis was to identify the patterns of a lesson, the sequences of behaviors and draw conclusions from the overall picture (McDonough \& McDonough, 1997; Schreier, 2014;Talmy, 2010).

\section{Results}

\section{Educational Settings}

The courses operated under a variety of conditions. Some were funded by NGOs, while other courses operated on the basis of volunteer work offered by individuals. For instance, one of the studied courses was part of a Program funded by a foreign Humanitarian Aid Organization and implemented by Greek NGOs, while in another case, the course run under the supervision of a University Department in the context of a relevant initiative aiming at providing language education to migrants and refugees. Voluntary associations, like "Stekia Metanaston" in various cities, were also among the providers of such courses. Six of the studied courses were taking place in or at a close distance from refugee camps and targeted the camp's population ${ }^{4}$. With regard to the languages taught, Modern Greek was taught in 17 of the educational settings, English was taught in 3, and German was taught in one case. This variety of languages taught reflects the fact that a part of the learner population was waiting for permission to leave Greece and resettle in some other EU country. They were, thus, interested in learning languages other than Modern Greek too. The duration and frequency of courses also varied, ranging from 1.5 to 3 hours, once, twice or more times per week. Moreover, some of these courses were more organised, following a specific syllabus, diagnostic tests, initial and final assessment, while in other contexts the teachers were the only responsible for the syllabus and the overall content of the lessons. It should also be mentioned that in some educational settings there was an assistant teacher in addition to the main teacher or/and a translator to facilitate the whole teaching and learning process.

\section{Teachers' profile}

Turning now to the teachers, their age ranges from 24 to over 60 years. All of them held a bachelor's degree, with the exception of a young woman who was still an undergraduate university student at the time of the study. The vast majority of teachers had graduated from a Department with a pedagogical orientation (departments of Greek Philology, English Language and Literature, History and Archeology, Philosophy, Pedagogy and Psychology, Department of Primary education). However, a music and a theology graduate were also found among the teachers. Eight (8) of them held one (in some cases more than one) Master's degree in the Humanities or Social Sciences (Sociology, Social Anthropology, Political History etc.), while two teachers were doctoral students. It is noteworthy that in one of the educational settings, the teacher was supervised and

\footnotetext{
${ }^{4}$ It must be noted that the conditions under which each educational setting operates may have some impact on the language courses offered. Although this is a very interesting research question, it was not among the objectives of this study, and should be considered in future research. Therefore, in this section we only report the variety of conditions we identified in the studied settings.
} 
guided by a University professor specializing in Applied Linguistics in the context of an educational program for refugees implemented by the University of loannina. With regard to their language teaching experience, half of them had had experience in teaching adult immigrants and refugees, which ranged from 2 to 6 years, while the rest of them were either involved with such populations for the first time (while having experience in teaching other populations, e.g., adults) or taught in a language class for the first time. All in all, we can conclude that the teachers were well educated and displayed a strong sense of social responsibility. However, it should be highlighted that only a few of them had received special training in $\mathrm{L} 2$ teaching.

\section{Teachers' goals}

When asked about the course's goals, teachers replied in different ways. The majority of them described the goals in very general terms:

We focus on teaching mainly the basics, grammar and vocabulary, but also on helping the students be able to be engaged in various communicative situations. To put it more simply, [we focus on] teaching them to communicate and socially integrate in general. ${ }^{5}$

Others gave more precise descriptions of the goals, showing great sensitivity to the needs of the particular groups of students:

Precisely because we are teaching refugee kids (students) ${ }^{6}$ we should be very aware of their specific needs, we [..] should put emphasis on their cultural background, their expectations about the future, the language they want to use, for example, the vocabulary about their safety, their journey and so on and so forth rather than focus on very traditional curriculum and very traditional methods of learning which would not work in this context.

In all cases, teachers highlighted the fact that students needed to be communicatively competent, especially with regard to everyday interactions and basic survival skills. Given the limited time allotted to the courses, most teachers prioritized listening and speaking.

\section{Teachers' views on literacy}

An issue that came up repeatedly in the interviews was that of literacy in both the mother and target language. More specifically, eight teachers reported that their classes focus was placed on oral communication, while reading and particularly writing skills were not often practised and sometimes were totally neglected. The main reasons they provided for their choice was that these skills were less important for survival and the students themselves preferred practicing oral skills. Some teachers also pointed out that written language was particularly difficult for this group of students and, therefore, should be left for later stages of language teaching. These teachers' remarks regarding the difficulty of obtaining target language literacy seem to be connected with some other teachers' remarks regarding mother language literacy. More specifically, five teachers pointed out that a major difficulty they regularly faced with this audience was the fact

\footnotetext{
${ }^{5}$ The interviews were conducted in Greek. The excerpts quoted here were translated by the authors.

${ }^{6}$ The teacher here refers to a group of unaccompanied adolescents aged between 16 and 17 .
} 
that some students had limited or non-existent literacy skills in their mother tongue, which slowed down their learning pace considerably and led to particularly heterogeneous classes, making the teachers' work highly demanding. For example, one teacher highlighted that: "there are people who have graduated from university, there are people who are completely illiterate. All these people must coexist. This is the course".

\section{Students' profiles}

Regarding the students' profiles, diversity in their age, origin, educational level, duration of stay in Greece and work experience can be easily noticed. To be more precise, our sample consists of immigrants and refugees aged 15 to 63 years old that in most cases belong to the same class. They came from different parts of the world, such as Iran, Iraq, Bangladesh, Egypt, Pakistan, Afghanistan, Ethiopia, Syria, Spain, Ukraine, Romania, Georgia, Bulgaria, Congo, Turkey, Nigeria, Albania, France, Serbia, Lithuania, Russia, Lebanon, Algeria, FYROM, Morocco and Palestine, to name just a few. Moreover, their educational level significantly varied, as some of them had already attended secondary education or even held a Bachelor's degree in their home-country, while some of them had attended only primary education or were completely illiterate. Both illiterate and educated people were put in the same class. It should also be noted that some of them had a basic speaking competence in English, which sometimes facilitated the whole teaching process. In addition, their duration of stay in Greece varied, ranging from a few months (4-9) to a few years (2-8), while in a few cases they had been staying in Greece for more than 10 years. Drawing on the data of the study, it is evident that the newly arrived refugees were put in the same classes with those that had lived in Greece for some time. Last but not least, a huge variation can be identified in their work experience, as some of them had been involved in occasional employment, i.e. worked as a shop assistant, a waitress, a dressmaker etc., while most of them were unemployed.

\section{Students' goals}

When students were asked about the reasons for attending the specific courses, most of them replied that they wanted to become competent users of the Greek language in order to cope with everyday communicative needs, confirming, thus, the teachers' perceptions of their students' needs. Therefore, most of them were initially interested in obtaining oral competence. Then, their main worry was to learn the language in order to find a job and make ends meet. In addition to the above reasons, some of them replied that they were highly interested in integrating into the Greek society and becoming part of the Greek culture. Furthermore, some people, especially those who had been staying in Greece for some time, answered that they were keen on participating in exams to acquire a Greek certificate and getting the Greek citizenship in the near future. Few people, though, answered that they were attending language lessons to spend their time pleasantly and creatively, since they were feeling rather secluded and bored in the camps.

\section{Educational materials}

Regarding the teaching materials used in these educational settings, in seven cases teachers did not utilise any specific second language learning material for their classes, but they designed and implemented their own materials tailored to their students' needs, as they perceived them. In courses, particularly, where oral skills had been prioritised, teachers exploited audiovisual materials for their lessons. Recorded 
dialogues, music videos, pictures and other realia were used to prompt conversations. Other teachers enriched these materials with written texts and exercises from various sources. In one course, the teacher actually put together material, i.e. grammar drills, addressed to mainstream elementary school students, creating, thus, a grammatical syllabus, as she described it:

We work with books. The truth is that there was no material, no syllabus to rely on. We began from grammatical structures, which are of great importance, I mean we started from verbs, from the tenses so that they understand the various verb forms, then nouns, then adjectives, how to include them in a sentence, how to write a sentence, how to reply to a question with examples.

In the rest 14 educational contexts that were investigated, the teachers utilised materials especially designed for second language learners. When students could afford to buy a coursebook, one of the general purpose commercial textbooks was used, i.e. "Epikoinoniste Ellinika 1" (Arvanitakis \& Arvanitaki, 2010), "Ellinika A"” (Simopoulos, Pathiaki, Kanellopoulou \& Pavlopoulou, 2010), "Taxidi stin Ellada 2" (Gkareli et al., 2013) "Klik sta Ellinika 1" (Karakirgiou \& Panagiotidou, 2014). Most of these textbooks are addressed to early beginners of the Greek language_and are mainly A1/A2 or B1 level according to the levels set by the CEFR (Council of Europe, 2001). These textbooks presuppose a level of literacy in the mother tongue and a degree of familiarization with the functions and conventions of written discourse. Moreover, they are mainly material containing linguistically controlled reading passages, dialogues and tasks that simulate everyday occasions, which are almost mechanically reproduced through pseudocommunicative language role plays and exercises (Long, 2014). In cases where students could not afford to buy textbooks, i.e. in the majority of the educational settings studied, open textbooks and other materials that are available free of charge were utilised by the teachers. Some of these materials are the result of the large scale educational programs aiming at improving the education provided to minority students in Greece, while others address the needs of adult immigrants and refugees, especially at the very initial stages of language learning (e.g., "Gephires" [Simopoulos, 2016], "Enkheiridio ekmathisis tis ellinikis glossas se metanastes kai prosphiges" [Katalipsi Sinialo, 2012]). It is worth noting that in two cases of English language teaching to refugees, the coursebooks "English for starters 1" (Nasr \& Dallas, 2007) and "English for starters 3" (Hancock, 2006), addressed to Syrian primary school students were used. These books have the advantage of referring to situations and places familiar to many students, but address the needs of a different age group in a completely different context.

\section{Teaching methods adopted in these educational settings}

Though the majority of teachers reported that they adopted the communicative teaching emphasizing the spoken language (see, for instance, the following excerpt from an interview with a teacher), it was observed that when they were asked to put theory into practice, in essence, they followed a more traditional method.

In my class, I aim at integration, namely not only the language, and for this reason I am not very strict with errors [..] I focus on oral language and on the so called communicative method, and afterwards on the written language, although we did a lot of work on written language. 
In other words, they applied a combination of aspects of the various teaching approaches, such as the Audio-lingualism, the Grammar-translation, the PresentationPractice-Production, the Direct method, focusing mainly on form (Long, 2014). In most cases, their teaching methods involved the provision of language elements through the use of small chunks, drills, information- gap activities, dialogues and controlled roleplaying (Rodgers, 2009), which sometimes included group activities.

\section{Relationships}

Focusing on the climate of the learning environment, based on the interview findings it is evident that the teachers paid special attention to the creation of a supportive environment for their students. They built a personal relationship with their students and took into account cultural and age differences, being genuinely concerned about what went on among their learners. One of the teachers during the interview said: "it's all about creating a friendly atmosphere in which you feel really safe to learn and I really like the interaction, how humane this project is". Another teacher mentioned: "It's magnificent that you will see those people help each other although they might not even know each other, they actually help each other, they work as one team focusing on the tasks", while a third one reports "I try to encourage more proficient (students) to help out those that are not so good and have more troubles/problems?". In the learners' view teachers were "friendly and help me every time for everything", "helpful and excited" and "[hard]working".

Finally, classroom observation confirmed joint problem solving and cooperation among the learners; it was obvious that the educational setting united and solved conflicts even with cross-cultural religious differences. In most cases, a positive, cooperative and cordial learning environment was prevalent based on dialogue, mutual trust and respect. Namely, the teachers tried to do their best in order to create a cozy, friendly but simultaneously professional classroom atmosphere, which encouraged learners to actively participate in the lesson, express their ideas, ask for questions/clarifications and seek guidance and feedback, and eventually assimilate knowledge and become confident learners.

In addition, the students' contributions to the whole teaching process should be pointed out, which were encouraged not only by their peers but also by their teachers. More often than not, the more advanced language learners were encouraged to facilitate each other's efforts to acquire knowledge or accomplish tasks, especially whenever their teacher could not explain something even through the use of English. For example, some of the students, who understood the language better, tried to explain the new structures using English or some other home language, translated words for their classmates when they faced difficulty, while it has been observed that the "weak" students did not hesitate to ask a more advanced student for explanations. According to the observation data, it is very interesting to mention that it was not necessary for the teacher to provide explanations, as the learners did so anyway. In other words, students were engaged in cooperative group learning and made joint efforts to understand new input.

Overall, in most cases it was shown that teachers did their best to create a pleasant and supportive learning environment for students, enhance their self-esteem, and accept students' diversity, which boosted their motivation to participate in the whole learning process without any feelings of competition or conflict. 


\section{Discussion}

The main aim of this study was to explore the teachers' and students' profiles and goals, the teaching procedures, the educational materials and the classroom climate in non-formal educational settings that offer free language courses to immigrants and refugees aged 15 and above. It was revealed that students in these educational settings differ in age, origin, educational level, socio-cultural background, duration of stay in Greece, and work experience, which is in accordance with relevant literature stating that the educational settings where second language learning occurs consist of people of all ages, social classes, and educational backgrounds making the teachers' job highly demanding (Long, 2014). Similarly, Beacco et al. (2017) highlighted that migrant populations differ socially, culturally, and linguistically including both illiterate people and people with advanced literacy skills. They conclude that "...there is no such thing as a typical migrant" (Beacco et al., 2017, p. 4) and, as a result, differentiated courses adjusted to the learners' particular needs and characteristics should be designed.

Especially with regard to literacy, there is no doubt that learners with interrupted formal education and low literacy skills in their first language have their own special needs and are known to face great challenges in mainstream L2 education (Fanta-Vagenshtein, 2011; Marrapodi, 2013). Recent research indicates that literacy in the first language has an effect on the development of both oral and written skills in a second language (Tarone, Bigelow, \& Hansen, 2007, 2009). Many teachers in our sample pointed out emphatically the difficulties faced by such students. Moreover, this study revealed that there is mainly emphasis on oral skills in these language courses, as, according to the immigrants' and refugees' goals, they need to be communicatively competent and seek to satisfy very basic survival needs and everyday interactions in the new country. This is a justifiable goal at the first stages of language acquisition, when vital needs need to be addressed in a short time. However, the successful integration and acculturation of the newcomers into the host society depends greatly on their literacy skills (Adami, 2008; Androulakis et al., 2016). Our study indicates that more research needs to be conducted with regard to the literacy skills of adult immigrants that attend language courses within the Greek context. Additionally, courses must be designed and implemented with emphasis on literacy, taking into consideration the literacy profiles proposed by the Council of Europe. As indicated by Plutzar and Ritter (2008) "[l]iteracy provision for migrants is more successful if it is combined with language support" (p. 35), so that both needs, literacy and language learning, are met simultaneously.

With regard to teaching practices, our findings are in line with the findings of Pathiaki and Simopoulos (2014). The teachers in our sample, who are highly educated individuals but often lacking the necessary know-how, adopted a more traditional approach to language teaching focusing mainly on form (Long, 2014), despite the fact that they reported that they adopted the communicative approach. The teaching materials used reflect the general orientation on the courses. Namely, in most cases, tutors use materials especially designed for second language learners, which place an emphasis on forms (Long, 2014), although there is some variation among teachers with regard to this parameter. At the same time, the climate in the educational settings studied, was found to be positive and cooperative in most cases. The teachers have created a cordial learning environment based on dialogue, mutual trust and respect, despite the learners' diversity. Namely, the teachers did their best to create a pleasant and supportive learning 
environment for students, transmit feelings of confidence to them, praise and encourage them to actively participate in the teaching process, help them express their ideas and ask questions or even help their peers (Arnold, 2011).

Concurrently, the important role of the associations and volunteers who organize learning activities for migrants and refugees should be emphasized. There is no doubt that the teachers try to do their best in order to help this vulnerable population learn the language in a cozy, friendly but at the same time professional classroom atmosphere. However, they need guidance with regard to the teaching goals, syllabus development, educational material used and method of instruction to help refugees and migrants acquire language based on their needs and the requirements of the host community. Teachers definitely need training and specialization in teaching language to refugees and migrants through especially designed seminars (Celani, 2006). The toolkit that has been developed by the Council of Europe in the context of the "Linguistic Integration of Adult Migrants - LIAM" project, aiming at providing assistance to organizations and volunteers working with refugees, is of tremendous importance. Its dissemination through carefully designed activities would provide a lot of help, impetus and coherence to the currently fragmented field ${ }^{7}$. Moreover, the identified call for courses in languages other than Modern Greek highlights the need for cooperation at a European level, at least as far as the population that is waiting to be resettled is concerned. Early and effective language education in the countries of entry is of vital importance for the process of smooth integration.

All in all, this is an exploratory study that attempted to look into the language education offered to refugees and immigrants in Greece free of charge. The results of the present study indicated that the field of language education provided to immigrants and refugees is fragmented, mainly depending on the initiatives taken by individuals or institutions operating on a local level. However, it should be mentioned that this study has one basic limitation that we need to consider. Namely, the same research tool was not possible to be used to collect the data in all cases. For example, each MA student developed his/her own interview guide and observation list to collect the data, though the aims of the study were common. As a result, more research is needed to verify the findings of this study and shed light on the type of language education offered to this vulnerable population.

Concluding, we should emphasize that, although the language education may not be the first priority of refugees, the majority of those participating in the classes observed were engaged in language learning and the entire educational setting probably was fulfilling other more urgent (and non-linguistic) needs related mainly to their vulnerable emotional state. Restoring their self-confidence, encouraging social interaction in the host country, fostering willingness to make plans for the future and, of course, raising their motivation and interest to communicate in the language of the host country were some of the needs that teachers in these settings were eager to respond to.

\footnotetext{
${ }^{7}$ https://www.coe.int/en/web/language-support-for-adult-refugees/
} 


\section{Acknowledgement}

We would like to express our gratitude to the students of the MA programme 'Language Education for Refugees and Migrants" of the Hellenic Open University attending the module 'Applied Linguistics \& Second Language Acquisition' during the academic year 2016-17, who helped collect the data: Alexandra Angelakou, Ourania Bouga, Olympia Filippopoulou, Eleftheria Florou, Ioannis Giantsidis, Marylou Glypti, Christina Kanavoura, Evaggelia Karpouzi, Despoina Kiamili, Aglaia Kokorelia, AriadniChristina Kontopoulou, Nafsika Koukopoulou, Eleftheria Mpanti, Zoi Ntota, Stavros Psaroudakis, Paraskevi Sarantopoulou, Eleni Triantafyllou, Panagiota Tsiami, Konstantinos Tsioupis, Efrosynh Vyzovitou, Evmorfia Zisi.

\section{References}

Adami, H. (2008). The role of literacy in the acculturation process of migrants. In Council of Europe (Ed.), Case studies: prepared for the Linguistic Integration of adult migrants seminar (pp. 19-27). Strasbourg. Retrieved from https://www.coe.int/t/dg4/Linguistic/Migrants CaseStudies08 EN.pdf

Androulakis, G., Gkaintartzi A., Kitsiou, R., \& Tsioli, S. (2017). Research-driven task-based L2 learning for adult immigrants in times of humanitarian crisis: results from two nationwide projects in Greece. In J. C. Beacco, H. J. Krumm, D. Little, \& P. Thalgott (Eds.), The linguistic Integration of adult migrants. Some lessons from research (pp. 181-186). Berlin/Boston: De Gruyter.

Androulakis, G., Mastorodimou, E., \& van Boeschoten, R. (2016). Using qualitative methods for the analysis of adult immigrants' $L 2$ needs: Findings from a research project in Greece focusing on school-parents Communication. Irish Journal for Culture, Arts, Literature and Language, 1(1), 1-19.

Arvanitakis, K. \& Arvanitaki, Ph. (2010). "Epikoinoniste Ellinika 1 [Communicate in Greek]. Athens: Deltos.

Beacco J. C., Krumm H. J., \& Little, D. (2017). Introduction. In J. C. Beacco, H. J. Krumm, D. Little, \& P. Thalgott (Eds.), The linguistic integration of adult migrants. Some lessons from research (pp. 1-5). Berlin/Boston: De Gruyter.

Bigelow, M., \& Schwarz, R. (2010). Adult English language learners with limited literacy. Washington DC: National Institute for Literacy.

Celani, M. A. (2006). Language teacher educators in search of locally helpful understandings. In S. Gieve \& I. K. Miller (Eds.), Understanding the English classroom (pp. 226-238). New York: Palgrave McMillan.

Fanta-Vagenshtein, Y. (2011). Literacy and second language intervention for adult Hebrew second language (HSL) learners. Journal of Language and Literacy Education, 7(1), 79-94.

Gkareli, E., Kapoula, E., Kontokosta, E., Montzoli, M., Nestoratou, S., Pritsi, E., Roumpis, N., \& Sikara, G. (2013). Taxidi stin Ellada 2 [Travel in Greece 2]. Athens: Ekdoseis Grigori.

Greek Council for Refugees. (2017). Access to education - Greece | Asylum Information Database. Retrieved from http://www.asylumineurope.org/reports/country/greece/receptionconditions/employment-and-education/access-education\#footnoteref7 rdnal1r

Hancock, M. (2006). English for starters 3. Pupil's book. London: York press. 
Karakirgiou, M. \& Panagiotidou, V. (2014). Klik sta Ellinika 1 [Click in Greek]. Thessaloniki: Centre for the Greek Language.

Katalipsi Sinialo. (2012). Enkheiridio ekmathisis tis ellinikis glossas se metanastes kai prosphiges [Greek language coursebook for migrants and refugees]. Retrieved from https://sinialo.espiv.net/wp-content/uploads/2012/05/immigrantsbook.pdf

Krumm, H-J., \& Plutzar, V. (2008). Tailoring language provision and requirements to the needs and capacities of adult migrants. Thematic Studies: The Linguistic Integration of Adult Migrants, Strasbourg: Council of Europe, 26-27 June 2008 (pp. 71-84). Retrieved from https://www.coe.int/t/dg4/linguistic/Migr ThematicStudies08 EN.pdf

Little, D. (2008). The Common European Framework of Reference for languages and the development of policies for the integration of adult migrants. Thematic Studies: The Linguistic Integration of Adult Migrants, Strasbourg: Council of Europe, 26-27 June 2008 (pp. 5-19).

Retrieved from https://www.coe.int/t/dg4/linguistic/Migr ThematicStudies08 EN.pdf

Marrapodi, J. (2013). What doesn't work for the lowest level literacy learners and why? Apples, 7(1), 7-23.

Mattheoudakis, M. (2005). Language education of adult immigrants in Greece: current trends and future developments. International Journal of Lifelong Education, 24(4), 319-336.

McDonough, J., \& McDonough, St. (1997). Research methods for English language teachers (1st ed.). London: Arnold.

Minuz, F., \& Borri, A. (2017). Literacy and language teaching: tools, implementation and impact. In J. C. Beacco, H. J. Krumm, D. Little, \& P. Thalgott (Eds.), The linguistic integration of adult migrants. Some lessons from research (pp. 357-364). Berlin/Boston: De Gruyter.

Nasr, R. T., \& Dallas, D. (2007). English for starters 1. Pupil's book. London: York press.

Nunan, D. (1992). Research methods in language learning (1st ed.). Cambridge: Cambridge University Press.

Pathiaki, I., \& Simopoulos, G. (2014). «Me vlepoun san anthropo»: Ta mathimata ellinikis glossas se metanastes kai prosphiges sto plaisio ton ethelontikon organoseon ["They see me as a human being": Greek language courses for immigrants and refugees in the framework of voluntary organizations]. In P. Georgogiannis (Ed.), Proceedings of the $11^{\text {th }}$ International Conference "Intercultural Education, immigration and Greek as a second or foreign language" (pp. 183-196). Patra: Intercultural Education Centre.

Patton, M. Q. (1990). Qualitative evaluation and research methods (2nd ed.). Newbury Park: Sage Publications.

Plutzar, V., \& Ritter, M. (2008). Language learning in the context of migration and integration Challenges and options for adult learners. In Council of Europe (Ed.), Case studies: prepared for the linguistic integration of adult migrants seminar (pp. 29-45). Strasbourg. Retrieved from https://www.coe.int/t/dg4/Linguistic/Migrants CaseStudies08 EN.pdf

Rodakopoulos, A., \& Lily, P. (2010). Ekpaideusi enilikon metanaston stin Elliniki Glossa: Entopismos kai diakheirisi provlimatikon katastaseon me ti khrisi methodologion domisis provlimaton [Teaching the Greek Language to adult migrants: Specifying and confronting problematic situations through the use of the methods of structuring problems]. In P. Georgogiannis \& V. Baros (Eds.), Proceedings of the $13^{\text {th }}$ International Conference "Intercultural Education Immigration - Conflict management and Pedagogy of Democracy" (pp. 255-261). Patra: Intercultural Education Centre. 
Ryan, G. W., \& Bernard, H. R. (2000). Data management and analysis methods. In N. K. Denzin \& Y. S. Lincoln (Eds.), Handbook of qualitative research (2nd Edition) (pp. 769-802). Thousand Oaks: Sage Publications.

Scientific Committee in Support of Refugee Children. (2017). Refugee education project: $A$. Assessment report on the integration project of refugee children in education (March 2016April 2017), B. Proposals for the education of refugee children during the 2017-2018 school year. Athens: Ministry of Education Research and Religious Affairs. Retrieved from http://www.minedu.gov.gr/publications/docs2017/CENG Epistimoniki Epitropi Prosfygo n YPPETH Apotimisi Protaseis 20162017070 .pdf

Schreier, M. (2014). Qualitative content analysis. In U. Flick (Ed.), The SAGE handbook of qualitative data analysis (pp. 170-183). London: Sage.

Simopoulos, G. (2016). Gephires [Bridges]. Retrieved from http://www.kanepgsee.gr/sitefiles/files/GEFYRES.pdf

Simopoulos, G., Pathiaki, Ei., Kanellopoulou, R., \& Pavlopoulou, A. (2010). Ellinika A'- Methodos ekmathisis tis ellinikis os xenis glossas [Modern Greek A - Teaching method for Modern Greek as a foreign language]. Athens: Patakis.

Talmy, S. (2010). Qualitative interviews in applied linguistics: From research instrument to social practice. Annual Review of Applied Linguistics, 30, 128-148. doi:10.1017/S0267190510000085

Tarone, E., Bigelow, M., \& Hansen, K. (2007). The impact of alphabetic print literacy level on oral second language acquisition. In N. Faux (Ed.), Low-educated second language and literacy acquisition. Research, policy, and practice. Proceedings of the second annual forum (pp. 99120). Richmond, Virginia: The Literacy Institute at Virginia Commonwealth University. Retrieved from http://www.leslla.org/files/resources/LESLLAProceedingsFinal.pdf

Tarone, E., Bigelow, M., \& Hansen, K. (2009). Literacy and second language oracy. Oxford: Oxford University Press.

Van Avermeat, P., \& Gysen, S. (2008). Language learning, teaching and assessment and the integration of adult immigrants: The importance of needs analysis. Thematic Studies: The Linguistic Integration of Adult Migrants, Strasbourg: Council of Europe, 26-27 June 2008 (pp. 59-70).

Retrieved from https://www.coe.int/t/dg4/linguistic/Migr ThematicStudies08 EN.pdf

Zarifis, G. K. (2016, May 2). Greece - solidarity with the 'others in need'. Retrieved from https://ec.europa.eu/epale/en/content/overview-refugees-and-adult-education-europe 